\title{
Hubungan Kejadian Karies Gigi dengan Konsumsi Air Minum pada Masyarakat di Indonesia
}

\author{
The Relationship of Dental Caries with Drinking Water Consumption on Community in Indonesia
}

\author{
Made Ayu Lely Suratri*, Tince A. Jovina, dan Indirawati Tjahja Notohartojo \\ Pusat Penelitian dan Pengembangan Sumber Daya dan Pelayanan Kesehatan, Badan Penelitian dan \\ Pengembangan Kesehatan, Kementerian Kesehatan RI, Jl. Percetakan Negara No. 29 Jakarta Pusat, \\ Indonesia \\ *Korespondensi Penulis: made.lely@gmail.com
}

Submitted: 05-07-2018; Revised: 28-08-2018; Accepted: 05-09-2018

DOI: https://doi.org/10.22435/mpk.v28i3.254

\begin{abstract}
Abstrak
Prevalensi karies gigi di Indonesia cukup tinggi, hasil Riset Kesehatan Dasar (Riskesdas) tahun 2013 penduduk Indonesia yang bermasalah dengan gigi dan mulutnya sebesar $25,9 \%$. Rata-rata karies gigi yang diukur dengan indeks DMF-T sebesar 4,6 yang berarti rata-rata penduduk Indonesia telah mengalami kerusakan gigi sebanyak 5 gigi per orang. Karies gigi dapat terjadinya karena rendahnya kebersihan gigi dan mulut, dan kurang terpaparnya dengan fluorida. Kejadian karies gigi berhubungan juga dengan kandungan fluor yang terdapat dalam air minum. Tujuan dari penelitian untuk mengetahui hubungan antara kejadian karies gigi dengan konsumsi air minum masyarakat di Indonesia. Metode penelitian ini merupakan penelitian non intervensi dengan desain penelitian potong lintang yang dilaksanakan oleh Badan Penelitian dan Pengembangan Kesehatan, Kementerian Kesehatan Republik Indonesia melalui Riskesdas Tahun 2013. Populasi penelitian adalah seluruh penduduk Indonesia yang berusia $\geq 12$ tahun di 33 provinsi, 497 kabupaten/kota. Pengumpulan data gigi dilakukan dengan melakukan wawancara dan pemeriksaan gigi dan mulut. Hasil penelitian menunjukkan hampir semua jenis sumber air minum dapat menyebabkan terjadinya karies gigi kecuali jenis air minum dari air isi ulang, dengan nilai $p>0,05$ ( $p=$ $0,178)$ dan air ledeng eceran, dengan nilai $p>0,05(p=0,307)$ dan juga hampir semua jenis sumber air yang banyak dipergunakan untuk kebutuhan rumah tangga dapat menyebabkan terjadinya karies gigi kecuali jenis sumber air dari sumur gali terlindungi, dengan nilai $p>0,05(p=0,979)$, dimana OR: 1,026 $(\mathrm{Cl}$ 95\%: 0,979-1,076). Kesimpulan penelitian menunjukkan kejadian karies gigi ada hubungannya dengan konsumsi air minum kecuali jenis air minum dari air isi ulang.
\end{abstract}

Kata kunci : karies gigi; air minum; masyarakat

\begin{abstract}
The prevalence of dental caries in Indonesia is quite high, the results of the 2013 Basic Health Research (Riskesdas) population in Indonesian with $25,9 \%$ problems with their teeth and mouth. The average dental caries measured by the DMF-T index was 4.6, which means that the average Indonesian population has experienced tooth decay as much as 5 teeth per person. Dental caries can occur due to low dental and oral hygiene, and less exposure to fluorida. The incidence of dental caries is also related to the fluorine content contained in drinking water. The purpose of the study was to determine the relationship between dental caries and drinking water consumption in Indonesia. This study is a non-intervention research with cross-sectional design conducted by the National Institute of Health Research and Development, Ministry of Health of the Republic of Indonesia through Riskesdas 2013. The study population was all Indonesians aged $\geq 12$ years in 33 provinces, 497 districts/cities. Collecting Dental data is done by conducting interviews and oral and dental examinations. The results showed that almost all types of drinking water sources can cause dental caries except the type of drinking water from refill water, with $p>0,05(p=0,178)$ and retail tap water, with $p>0,05(p=0.307)$ and also almost all types of water sources that are widely used for
\end{abstract}


household needs can cause dental caries except the type of water source from dug well is protected, with $p>0,05(p=0,979)$, where OR: 1,026 (Cl $95 \%$ : 0.979-1.076). The Conclusio is the incidence of dental caries has to do with at the drinking water except the type of drinking water from refill water.

Keywords : dental caries; drinking water; community

\section{PENDAHULUAN}

Karies gigi adalah salah satu penyakit gigi dan mulut yang paling sering ditemui di masyarakat yang merupakan penyakit infeksi yang disebabkan oleh demineralisasi email dan dentin yang erat hubungannya dengan konsumsi makanan yang kariogenik. ${ }^{1,2}$ Terjadinya karies gigi akibat peran dari bakteri penyebab karies yang terdapat pada golongan Streptoccocus dalam mulut yang secara kolektif disebut Streptoccocus mutans. Indonesia menghadapi tantangan yang berkaitan dengan status kesehatan gigi dan mulut yang buruk pada anak-anak. Masalah ini berlanjut sampai usia remaja dan dewasa, dimana lebih dari $70 \%$ mempunyai pengalaman yang berkaitan dengan karies gigi. ${ }^{3}$

Prevalensi karies gigi di Indonesia memiliki derajat keparahan yang cukup tinggi. Hasil Riset Kesehatan Dasar (Riskesdas) tahun 2013 menunjukkan prevalensi penduduk Indonesia yang bermasalah dengan gigi dan mulutnya sebesar $25,9 \%$. Rata-rata karies gigi yang diukur dengan indeks DMF-T sebesar 4,6 yang berarti rata-rata penduduk Indonesia telah mengalami kerusakan gigi sebanyak 5 gigi per orang. ${ }^{4}$ Karies gigi dapat terjadi karena rendahnya kebersihan gigi dan mulut, sering makan makan yang manis dan lengket, dan kurang terpaparnya dengan fluorida. Kejadian karies gigi berhubungan juga dengan kandungan fluor yang terdapat dalam air minum, disamping juga berhubungan dengan adanya gangguan produksi air liur (cairan saliva). ${ }^{5}$ Adanya peningkatan prevalensi karies gigi dapat menghambat kesehatan masyarakat secara umumnya.

Salah satu tujuan Oral Health 2020 yang telah disepakati oleh World Health Organization (WHO), Federation Dental International (FDI), dan International Assosiation for Dental Research (IADR), untuk penyakit karies gigi di dunia khususnya Indonesia adalah mengurangi komponen $\mathrm{M}$ (missing) atau kehilangan gigi akibat karies gigi pada usia 18 tahun, 35-44 tahun, dan 65-74 tahun. Berbagai indikator telah ditentukan WHO, antara lain anak umur 12 tahun mempunyai indeks Decayed, Missing, Filled-Tooth (DMF-T) sebesar 1, penduduk umur 18 tahun tidak ada satupun gigi yang dicabut $(\mathrm{M}=0)$, dan penduduk umur 35-44 tahun memiliki minimal 20 gigi berfungsi sebesar $90 \%$ dan umur $\geq 65$ tahun dengan minimal 20 gigi berfungsi sebesar $75 \%$ (Riskesdas, 2007). ${ }^{6}$ WHO pada tahun 2010, menargetkan indeks DMF-T adalah 1,0 sedangkan negara berkembang menetapkan indeks karies adalah1,2.

Penelitian yang dilakukan di India oleh Shekar ${ }^{7}$ menunjukkan adanya hubungan langsung antara sikap, perilaku, dan status sosial ekonomi dengan kebersihan gigi dan mulut. Perilaku atau kebiasaan merupakan hal penting yang dapat mempengaruhi status kesehatan gigi individu atau masyarakat. Hasil penelitian Warni $\mathrm{L}^{8}$ bahwa perilaku yang dapat mempengaruhi perkembangan karies adalah kebiasaan melakukan pemeliharaan kebersihan gigi dan mulut misalnya menggosok gigi secara teratur. Menurut Sami, Vichayanrat, dan Pratana, ${ }^{9}$ tidak ada hubungan antara kebiasaan menyikat gigi, penggunaan pasta, penggunaan miswak, dan kunjungan ke dokter gigi dengan karies gigi, dimana karies gigi anak-anak itu berhubungan dengan kebiasaan sehari-hari mengonsumsi kue kering dan jus segar. Data Riskesdas 2013 menunjukkan perilaku masyarakat tentang pemeliharaan kesehatan gigi pada kelompok penduduk $\geq 10$ tahun dengan proporsi menyikat gigi setiap hari sebesar $93,8 \%$, tapi kebiasaan penduduk Indonesia menyikat gigi dengan benar (sesudah makan pagi dan sebelum tidur malam) hanya $2,3 \%{ }^{4}$

Karies gigi dapat dicegah dengan menyikat gigi secara rutin minimal dua kali sehari, yaitu setiap sesudah makan dan hendak tidur malam. Kebiasaan menyikat gigi, juga dapat mempengaruhi berat ringannya karies, responden yang sikat gigi mempunyai kecenderungan terjadinya karies lebih ringan dibandingkan yang tidak sikat gigi. ${ }^{9}$

Standar air bersih yang dapat digunakan oleh masyarakat harus memenuhi syarat fisik, kimia, bakteriologis, dan radio aktif. Zat kimia yang terdapat di dalam air salah satunya adalah fluor. Tubuh membutuhkan fluor untuk proses metabolisme, dan bila kadar fluor lebih besar dari $2,5 \mathrm{mg} / 1$ dapat mengakibatkan penyakit perut, tulang keropos, dan email gigi berwarna coklat. Kekurangan fluor dapat menyebabkan kerusakan gigi, gigi menjadi rapuh, mudah terserang karies gigi (caries dentis), perubahan warna pada gigi anak, dan dapat terjadi penipisan tulang. ${ }^{10}$

Konsentrasi fluor dalam air berhubungan 
erat dengan jenis sumber air. Pada umumnya konsentrasi fluor di air tanah dan air permukaan melebihi syarat yang ditetapkan. Konsentrasinya dalam air tanah biasanya lebih tinggi daripada air permukaan, bahkan di beberapa tempat terkadang sangat tinggi. Tingginya kadar fluor dalam air dapat membahayakan kesehatan gigi jika tidak ada pengolahan (defluoridasi). Sebaliknya pada jenis sumber air minum lain seperti air hujan, kandungan fluor-nya rendah di bawah syarat yang ditetapkan. Rendahnya kandungan fluor dalam air juga dapat menyebabkan karies gigi sehingga perlu untuk dilakukan fluoridasi. ${ }^{11}$

Status kesehatan gigi dan mulut sangat erat hubungannya dengan perilaku atau kebiasaan dari masyarakat dalam pemeliharaan kesehatan gigi dan mulutnya dan juga kondisi dari air minumnya. Penelitian ini bertujuan untuk mengetahui hubungan kejadian karies gigi dengan konsumsi air minum masyarakat di Indonesia

\section{METODE}

Penelitian ini merupakan penelitian non intervensi dengan desain penelitian potong lintang (cross-sectional) yang dilaksanakan oleh Badan Penelitian dan Pengembangan Kesehatan, Kementerian Kesehatan Republik Indonesia melalui Riskesdas) tahun 2013. Populasi penelitian adalah seluruh penduduk Indonesia yang mencakup 33 provinsi, 497 kabupaten $/$ kota. $^{4}$
Sampel adalah semua anggota rumah tangga yang telah berusia $\geq 12$ tahun dan menandatangani informed consent (persetujuan dilakukan penelitian). Pengumpulan data gigi dilakukan dengan melakukan pemeriksaan gigi dan mulut yang sebelumnya dilakukan penyamaan persepsi dibawah pengawasan pakar yang berpengalaman di lapangan. Penyamaan persepsi dilakukan untuk memastikan bahwa penilaian yang dilakukan peneliti setara dengan penilaian yang dilakukan para pakar. Riskesdas 2013 ini telah mendapatkan persetujuan etik dari Komisi Etik Penelitian Kesehatan Republik Indonesia, Nomor. 01.1206.207

Analisis data dilakukan secara univariat, bivariat, dan multivariat dengan menggunakan logistik regresi. ${ }^{12}$ Pelaksanaan pengumpulan data kesehatan gigi dan mulut dilakukan melalui observasi/pemeriksaan gigi (untuk memperoleh indeks DMF-T) dengan menggunakan instrumen kaca mulut dengan bantuan penerangan sinar matahari atau lampu senter. Sedangkan untuk mengetahui perilaku atau kebiasaan, kualitas fisik dan pengolahan air minumnya dengan melakukan wawancara menggunakan kuesioner.

\section{HASIL}

Jumlah responden usia $\geq 12$ tahun yang dilakukan wawancara dan pemeriksaan gigi dan memenuhi syarat adalah sebanyak 189.080 orang.

Tabel. 1 Karakteristik Responden

\begin{tabular}{|c|c|c|c|c|}
\hline \multirow{2}{*}{$\begin{array}{c}\text { Karakteristik } \\
\text { Responden }\end{array}$} & \multirow[t]{2}{*}{ Jumlah } & \multirow[t]{2}{*}{$\%$} & \multicolumn{2}{|c|}{ Karies gigi } \\
\hline & & & Tidak Ada & Ada \\
\hline \multicolumn{5}{|l|}{ Kelompok Umur } \\
\hline 12-25 tahun & 54.968 & 29,07 & 22.803 & 32.165 \\
\hline 26-45 tahun & 74.402 & 39,35 & 12.982 & 62.420 \\
\hline 45-65 tahun & 48.389 & 25,59 & 2.947 & 45.442 \\
\hline$>65$ tahun & 11.321 & 5,99 & 214 & 11.107 \\
\hline Jumlah & 189.080 & 100 & 38.946 & 150.134 \\
\hline \multicolumn{5}{|l|}{ Jenis kelamin } \\
\hline Laki-laki & 91.052 & 48,15 & 20.842 & 70.210 \\
\hline Perempuan & 98.028 & 51,85 & 20.081 & 77.947 \\
\hline Jumlah & 189,080 & 100 & 40.923 & 148.157 \\
\hline \multicolumn{5}{|l|}{ Pendidikan } \\
\hline$<$ tidak tamat $\mathrm{SD}$ & 37.362 & 19,76 & 5.854 & 31.508 \\
\hline Tamat SD-SLTA & 139.565 & 73,81 & 32.174 & 107.391 \\
\hline >Tamat SLTA & 5.189 & 2,74 & 1.154 & 4.035 \\
\hline Tamat PT & 6.964 & 3.69 & 1.518 & 5.446 \\
\hline Jumlah & 189,080 & 100 & 40.700 & 148.380 \\
\hline \multicolumn{5}{|l|}{ Pekerjaan } \\
\hline Bekerja & 103.764 & 54,88 & 17.517 & 86.247 \\
\hline Tidak Bekerja & 85.316 & 45,12 & 23.560 & 61.756 \\
\hline Jumlah & 189,080 & 100 & 40.077 & 148.003 \\
\hline \multicolumn{5}{|c|}{ Lokasi Tempat Tinggal } \\
\hline Perkotaan & 86.946 & 45,98 & 9.168 & 67.777 \\
\hline Perdesaan & 102.134 & 54,02 & 21.760 & 80.374 \\
\hline Jumlah & 189,080 & 100 & 40.928 & 148.152 \\
\hline
\end{tabular}


Tabel 2. Hubungan Status Karies Gigi dengan Kebiasaan Menyikat Gigi yang

\begin{tabular}{|c|c|c|c|c|c|c|}
\hline \multicolumn{7}{|c|}{ Karies Gigi } \\
\hline \multirow[t]{2}{*}{ Menyikat gigi yang baik } & \multicolumn{2}{|c|}{ Tidak Ada } & \multicolumn{2}{|c|}{ Ada } & $\begin{array}{c}\text { OR } \\
\text { (Odds Ratio) }\end{array}$ & p Value \\
\hline & $\mathrm{n}$ & $\%$ & $\mathrm{n}$ & $\%$ & & \\
\hline Ya & 1.154 & 23,56 & 3.746 & 76,44 & 1,005 & 0,928 \\
\hline Tidak & 39.848 & 21,64 & 144.332 & 78,36 & & \\
\hline Jumlah & 41.002 & 20,34 & 148.078 & 79,66 & & \\
\hline
\end{tabular}

Tabel 3. Hubungan Status Karies Gigi dengan Jenis Sumber Air Minum

Karies Gigi

\begin{tabular}{|c|c|c|c|c|c|c|}
\hline \multirow[t]{2}{*}{ Jenis Sumber air minum } & \multicolumn{2}{|c|}{ Tidak Ada } & \multicolumn{2}{|c|}{ Ada } & \multirow[t]{2}{*}{$\begin{array}{c}\text { OR } \\
\text { (Odds Ratio) }\end{array}$} & \multirow[t]{2}{*}{ p Value } \\
\hline & n & $\%$ & n & $\%$ & & \\
\hline Air isi ulang & 8.824 & 23,51 & 28.703 & 76,49 & 1,050 & 0,178 \\
\hline Air ledeng/PDAM & 6.035 & 21,31 & 22.287 & 78,69 & 1,193 & 0,000 \\
\hline Air ledeng eceran & 761 & 23,16 & 2.525 & 76,84 & 1,072 & 0,307 \\
\hline Sumur bor/pompa & 4.446 & 22,34 & 15.459 & 77,66 & 1,123 & 0,003 \\
\hline Sumur gali terlindungi & 8.826 & 20,69 & 33.834 & 79,31 & 1,238 & 0,000 \\
\hline Sumur gali tidak terlindungi & 1.974 & 18,91 & 8.466 & 81,09 & 1,385 & 0,000 \\
\hline Mata air terlindung & 2.996 & 21,00 & 11.274 & 79,00 & 1,215 & 0,000 \\
\hline Mata air tidak terlindungi & 1.254 & 18,47 & 5.536 & 81,53 & 1,426 & 0,000 \\
\hline Penampungan air hujan & 1.318 & 15,97 & 6.935 & 84,03 & 1,699 & 0,000 \\
\hline Air Sungai/danau/ irigasi & 1.225 & 20,95 & 4.623 & 79,05 & 1,218 & 0,000 \\
\hline
\end{tabular}

Tabel 4. Hubungan Status Karies Gigi dengan Cara Pengolahan Air Minum

\begin{tabular}{|c|c|c|c|c|c|c|}
\hline \multicolumn{7}{|c|}{ Karies Gigi } \\
\hline \multirow[t]{2}{*}{ Cara Pengolahan air minum } & \multicolumn{2}{|c|}{ Tidak Ada } & \multicolumn{2}{|c|}{ Ada } & \multirow[t]{2}{*}{$\begin{array}{c}\text { OR } \\
\text { (Odds Ratio) } \\
\end{array}$} & \multirow[t]{2}{*}{ p Value } \\
\hline & $\mathbf{n}$ & $\%$ & $\mathbf{n}$ & $\%$ & & \\
\hline Dengan pemanasan & 28.715 & & 28.703 & 76,49 & 1,050 & 0,178 \\
\hline 20,71 & 109.916 & 79,29 & 0,963 & 0,592 & & 0,000 \\
\hline \multirow{2}{*}{$\begin{array}{l}\text { Ditambahkan larutan tawas/ } \\
\text { klorin }\end{array}$} & 761 & 23,16 & 2.525 & 76,84 & 1,072 & 0,307 \\
\hline & 29 & & 15.459 & 77,66 & 1,123 & 0,003 \\
\hline 15,86 & 156 & 84,14 & 1,384 & 0,270 & & 0,000 \\
\hline $\begin{array}{l}\text { Disaring dan ditambahkan } \\
\text { larutan tawas }\end{array}$ & 58 & & 8.466 & 81,09 & 1,385 & 0,000 \\
\hline 17.91 & 268 & 82,09 & 1,196 & 0,405 & & 0,000 \\
\hline Disaring/filtrasi & 247 & 19.05 & 1048 & 80,95 & 1,109 & 0,359 \\
\hline Penampungan air hujan & 1.318 & 15,97 & 6.935 & 84,03 & 1,699 & 0,000 \\
\hline Air Sungai/danau/ irigasi & 1.225 & 20,95 & 4.623 & 79,05 & 1,218 & 0,000 \\
\hline
\end{tabular}

Tabel 5. Hubungan Status Karies Gigi dengan Jenis Sumber Air yang Paling Banyak Dipergunakan untuk Keperluan Rumah Tangga

\begin{tabular}{|c|c|c|c|c|c|c|}
\hline \multicolumn{7}{|c|}{ Karies Gigi } \\
\hline $\begin{array}{l}\text { Jenis Sumber air yang paling } \\
\text { banyak dipergunakan }\end{array}$ & \multicolumn{2}{|c|}{ Tidak Ada } & \multicolumn{2}{|c|}{ Ada } & \multirow{2}{*}{$\begin{array}{c}\text { OR } \\
\text { (Odds Ratio) }\end{array}$} & \multirow[t]{2}{*}{ p Value } \\
\hline & $\mathbf{n}$ & $\%$ & $\mathbf{n}$ & $\%$ & & \\
\hline Air ledeng/PDAM & 10.482 & 22,32 & 36.486 & 77,68 & 0,891 & 0,043 \\
\hline Sumur bor/pompa & 7.873 & 23,35 & 25.838 & 76,65 & 0,933 & 0,009 \\
\hline Sumur gali terlindungi & 11.957 & 21,69 & 43.181 & 78,31 & 1,026 & 0,979 \\
\hline Sumur gali tidak terlindungi & 3.358 & 19,48 & 13.883 & 80,52 & 1,175 & 0,000 \\
\hline Mata air terlindung & 2.828 & 20,87 & 10.726 & 79,13 & 1,078 & 0,033 \\
\hline Mata air tidak terlindungi & 1.278 & 18,13 & 5.775 & 81,87 & 1,284 & 0,000 \\
\hline Penampungan air hujan & 807 & 18,36 & 3.592 & 81,64 & 1,264 & 0,000 \\
\hline
\end{tabular}




\begin{tabular}{lllllll} 
Air Sungai/danau/ irigasi & 2.037 & 18,50 & 8.976 & 81,50 & 1,252 & 0,000 \\
Penampungan air hujan & 1.318 & 15,97 & 6.935 & 84,03 & 1,699 & 0,000 \\
Air Sungai/danau/ irigasi & 1.225 & 20,95 & 4.623 & 79,05 & 1,218 & 0,000 \\
\hline
\end{tabular}

Jumlah responden yang paling banyak (pada Tabel 1) adalah kelompok umur 26-45 tahun $(39,35 \%)$, dimana responden perempuan lebih banyak daripada laki laki (51,85\%). Untuk tingkat pendidikan, yang paling banyak responden dengan pendidikan tamat SD sampai SLTA (73,81\%). Responden yang bekerja mempunyai karies gigi lebih banyak daripada yang tidak bekerja. Untuk lokasi tempat tinggal, responden yang tinggal di perdesaan mempunyai karies gigi lebih banyak daripada yang diperkotaan.

Terjadinya karies gigi tidak hanya dihubungkan dengan waktu menyikat gigi tetapi bagaimana teknik menyikat gigi yang benar seperti yang disebutkan dari data di atas. Tidak terdapat hubungan yang signifikan antara status karies gigi dengan kebiasaan menyikat gigi (Tabel $2)$, dengan nilai $p>0,05(p=0,928)$, ini berarti tidak ada hubungan yang bermakna, dimana $\mathrm{OR}=$ 1,005 (95\%, CI: 0,898-1.125).

Hampir semua jenis sumber air minum dapat menyebabkan terjadinya karies gigi kecuali jenis air minum dari air isi ulang (Tabel 3), dengan nilai $p>0,05(p=0,178)$ dan air ledeng eceran, dengan nilai $p>0,05(p=0,307)$.

Tidak terdapat hubungan yang signifikan antara cara pengolahan air minum dengan terjadinya karies gigi (Tabel 4), dengan nilai $\mathrm{p}>0,05$, ini berarti tidak ada hubungan yang bermakna antara cara pengolahan air minum dengan status karies gigi. Cara pengolahan air minum dapat menyebabkan terjadinya perubahan kandungan fluor pada air minum seperti adanya penambahan larutan tawas dalam dosis yang tepat dapat menyebabkan terjadinya proses penyerapan fluor pada air minum, sehingga kadar fluor menurun setelah proses penambahan larutan tawas. ${ }^{11}$

Hampir semua jenis sumber air yang banyak dipergunakan untuk kebutuhan rumah tangga dapat menyebabkan terjadinya karies gigi kecuali jenis sumber air dari sumur gali terlindungi (Tabel 5), dengan nilai $\mathrm{p}>0,05(\mathrm{p}=$ 0,979), dimana OR: 1,026 (CI 95\%: 0,979-1,076).

\section{PEMBAHASAN}

Jumlah responden 189.080 orang dimana hampir sebagian besar responden 150.626 responden $(79,66 \%)$ mempunyai karies gigi, jumlah responden yang mempunyai karies gigi paling banyak pada kelompok umur 2645 tahun $(41,23 \%)$. Responden perempuan dijumpai lebih banyak daripada responden laki laki (51,84\%), dan karies gigi lebih banyak pada responden dengan kelompok pendidikan tamat SD sampai SLTA. Hasil penelitian dari Melur ${ }^{13}$ diketahui indeks DMF-T rata-rata yang lebih tinggi pada ibu-ibu rumah tangga dengan tingkat pendidikan rendah, sebaliknya ibu rumah tangga dengan tingkat pendidikan tinggi mempunyai indeks DMF-T rata-rata yang lebih rendah. Hal ini menunjukkan bahwa makin tinggi tingkat pendidikan seseorang, angka indeks DMF-T nya makin rendah.

Hasil Riskesdas 2013 diketahui bahwa responden yang bekerja mempunyai karies gigi lebih banyak daripada yang tidak bekerja, sedangkan untuk lokasi tempat tinggal, responden yang tinggal di perdesaan mempunyai karies gigi lebih banyak daripada yang diperkotaan. Sementara hasil penelitian pada orang dewasa yang dilaporkan oleh Costa $^{14}$ bahwa sosial ekonomi, pendidikan, dan pekerjaan berpengaruh terhadap terjadinya karies gigi, dimana pada orang dengan sosial ekonomi yang rendah, ditemukan karies gigi yang lebih parah. Ini berarti bahwa faktor pekerjaan tidak terlalu berpengaruh terhadap terjadinya karies gigi.

Penelitian di Lithuhania tahun 2016, dilaporkan prevalensi karies gigi yang relatif tinggi, dan adanya perbedaan pengalaman karies gigi antara masyarakat yang di perkotaan dan pedesaan. Hal ini dipengaruhi oleh adanya perbedaan sosial ekonomi. Nilai DMF-T di daerah pedesaan lebih tinggi daripada daerah perkotaan, dimana pada laki-laki nilai DMF-T nya lebih tinggi daripada perempuan. ${ }^{15,16}$ Hasil Riskesdas 2013 responden yang tinggal di pedesaan $(54,02 \%)$ lebih banyak daripada yang tingaal diperkotaan $(45,98 \%)$, sedangkan untuk status karies gigi hampir sama tinggi antara di pedesaan $(78,69 \%)$ dan di perkotaan $(77,95 \%)$. Hasil dari penelitian ini diketahui bahwa tidak terdapat hubungan yang signifikan antara status karies gigi dengan kebiasaan sikat gigi, dengan nilai $p>0,05 \quad(p=0,928)$, ini berarti tidak ada 
hubungan yang bermakna, dimana $\mathrm{OR}=1,005$ (95\%, CI: 0,898-1.125). Hasil Riskesdas 2007 dilaporkan bahwa responden yang menyikat gigi mempunyai kecenderungan terjadinya karies lebih ringan dibandingkan yang tidak menyikat gigi. ${ }^{17}$ Penelitian yang dilakukan di India, diketahui bahwa sikap dan perilaku yang positif terhadap kebersihan gigi dan mulut berhubungan dengan kondisi kesehatan gigi dan mulut yang lebih baik. ${ }^{18}$

Rugg-Gunn dalam Ejiofor ZI dkk ${ }^{19}$ menyebutkan dalam 20 tahun terakhir sebagian besar penelitian yang telah dilakukan dengan menggunakan studi cross-sectional untuk mengevaluasi keefektifan fluoridasi air untuk pencegahan karies gigi yang lebih baik. Fluoridasi air minum pada umumnya dianggap sebagai cara yang mudah dan aman untuk mencegah karies gigi di masyarakat. Mengingat fakta bahwa kandungan fluorida air keran dilaporkan tidak konsisten/sama di seluruh negara dan ada kecenderungan yang terlalu tinggi bila untuk dikonsumsi, maka untuk mengendalikan konsentrasi berbagai unsur termasuk fluorida sangat penting untuk memproduksi air mineral dalam kemasan. ${ }^{20}$

Hasil analisis Riskesdas 2013, menunjukkan hampir semua jenis sumber air minum dapat menyebabkan terjadinya karies gigi kecuali jenis air minum dari air isi ulang, dengan nilai $p>0,05(p=0,178)$ dan air ledeng eceran, dengan nilai $p>0,05(p=0,307)$. Hampir semua jenis sumber air yang banyak dipergunakan untuk kebutuhan rumah tangga dapat menyebabkan terjadinya karies gigi kecuali jenis sumber air dari sumur gali terlindungi, dengan nilai bermakna, $\mathrm{p}>0,05(\mathrm{p}=0,979)$, dimana OR: 1,026 (CI 95\%: 0,979-1,076). ${ }^{4}$ Jenis sumber air minum yang terlindung dapat menjadi faktor pencegah untuk terjadinya karies gigi. Sarana air yang terlindung dapat mengurangi kemungkinan air tercemar, baik secara bakteriologi maupun kimia. Konsentrasi fluorida dalam air berhubungan erat dengan jenis sumber air. Pada umumnya konsentrasi fluorida di air tanah dan air permukaan melebihi syarat yang sudah ditentukan. Konsentrasinya dalam air tanah biasanya lebih tinggi daripada air permukaan, sebaliknya pada jenis sumber air minum lain seperti air hujan kandungan fluornya rendah di bawah syarat yang ditentukan. Rendahnya kandungan fluor dalam air juga dapat menyebabkan karies gigi sehingga perlu dilakukan fluoridasi. ${ }^{11}$ Widana $^{21}$ melaporkan bahwa kadar fluor dalam air pada mata air, air PAM, air minum isi ulang dalam kemasan gallon, dan air minum kemasan bermerek masih memenuhi syarat yang ditentukan rata rata dibawah $1,5 \mathrm{mg} / \mathrm{mL}$.

Hasil penelitian dari Ramezani $\mathrm{dkk}^{22}$ bahwa ditemukan kadar fluorida pada air minum yang sangat rendah di daerah perkotaan di Iran dimana hal ini sangat mengkhawatirkan dan memerlukan perhatian dari pemerintah. Pada daerah dengan kadar fluorida yang lebih tinggi cenderung karies giginya rendah tapi fluorosisnya meningkat. Pada penelitian yang dilakukan di Australia oleh Slade $\mathrm{dkk}^{23}$ dengan sampel orang usia dewasa yang mewakili secara nasional, efek dari fluoridasi air minum terhadap pencegahan karies-gigi pada orang dewasa hampir sama baiknya sebelum pelaksaanan fluoridasi dengan sesudah pelaksaanan fluoridasi secara luas.

\section{KESIMPULAN}

Beberapa jenis sumber air minum dapat menyebabkan terjadinya karies gigi kecuali jenis air minum dari air isi ulang, dan air ledeng eceran. Untuk cara pengolahan air minum tidak ada hubungannya dengan terjadinya karies gigi. Hampir semua jenis sumber air yang banyak dipergunakan untuk kebutuhan rumah tangga dapat menyebabkan terjadinya karies gigi kecuali jenis sumber air dari sumur gali terlindungi.

\section{SARAN}

Untuk mencegah atau mengurangi terjadinya karies gigi dengan mengonsumsi air minum dari jenis sumber air minum isi ulang dan air ledeng, serta menggunakan jenis sumber air dari sumur gali yang terlindungi untuk kebutuhan rumah tangga. Menjaga dan meningkatkan kebersihan gigi dan mulut dengan memeriksakan gigi secara periodik ke fasilitas pelayanan kesehatan gigi terutama untuk masyarakat di daerah pedesaan.

\section{UCAPAN TERIMA KASIH}

Penulis mengucapkan terimakasih kepada Kepala Badan Litbang Kesehatan, Kementerian Kesehatan RI yang telah memberikan izin untuk membuat artikel menggunakan data Riskesdas 2013. Terima kasih juga penulis ucapkan kepada Kepala Puslitbang Sumber Daya dan Pelayanan Kesehatan, Badan Litbang Kesehatan, Kementerian Kesehatan RI . 


\section{DAFTAR PUSTAKA}

1. Selwitz RS, Ismail AI, Pitts NB. Dental caries. The Lancet. 2007; Volume 369, Issue 9555: Page. 51-59.

2. Suratri MAL, Sintawati FX, Andayasari L. Pengetahuan, sikap, dan perilaku orang tua tentang kesehatan gigi dan mulut pada anak usia taman kanak-kanak di Provinsi Daerah Istimewa Yogyakarta dan Provinsi Banten Tahun 2014. Media Litbang Kesehatan. 2016;26(2):119-126.

3. Maharani DA. Inequity in dental care utilization in the Indonesian population with a self-assessed need for dental treatment. Tohoku J Exp Med. 2009;218(3):229-239. doi: 10.1620/tjem.218.229. [PubMed][Cross Ref].

4. Badan Litbang Kesehatan, Kemenkes RI. Pokok-pokok hasil riset kesehatan dasar (Riskesdas) tahun 2013. Jakarta: Kementerian Kesehatan RI; 2014: hal. 147-157.

5. PratiwiV,AripinD, SetiawanAS. Relationship between salivary fluor concentration and caries index in $12-15$ years old children. Dental Journal. 2012;5(1):35-38.

6. Badan Litbang Kesehatan, Kemenkes RI. Laporan riset kesehatan dasar (Riskesdas) tahun 2007. Jakarta: Kementerian Kesehatan RI; 2007: hal. 130-147.

7. Shekar BRC, Reddy CLK, Manjunath BC, Suma S. Dental health awareness, attitude, oral health-related habits, and behaviors in relations to socioeconomic factors among the municipal employees of mysore city. Annals of Tropical Medicine and Public Health. 2011;4(2):99-106.

8. Warni L. Relations student behavior grade $\mathrm{V}$ and VI on the dental and oral health of the dental caries status in the Old Deli, Districts of Deli Serdang. Research Report for Thesis. Faculty of Public Health, University of North Sumatra. 2009.

9. Sami E, Vichayanrat T, Pratana Satitvipawee P. Caries with dental fluorosis and oral health behaviour among 12-year school children in moderate-fluorida drinking water community in Quetta, Pakistan. Journal of the College of Physicians and Surgeons Pakistan. 2016;26(9):744-747.

10. Soerahman M, Rusmiati, Irawan DWP. Perbedaan kadar fluor pada air minum sumur gali sebelum dan sesudah proses koagulasi flokulasi kapur dan tawas. Jurnal Widya
Warta. 2012;2:361-374.

11. Musadad, Irianto D. Pengaruh penyediaan air minum terhadap kejadian karies gigi usia 1265 tahun di Provinsi Kep. Bangka Belitung dan Nusa Tenggara Barat. (Analisis Lanjut Riskesdas 2007). Jurnal Ekologi Kesehatan. 2009;8(3):1032-1046.

12. Hastomo SP. Health data analysis. Jakarta: Faculty of Public Health, University of Indonesia; 2007. hal. 65-107.

13. Melur T. Hubungan tingkat pendidikan dengan karies gigi pada ibu ibu rt usia 2045 tahun di Kelurahan Simpang Selayang, Kecamatan Medan Tuntungan [internet]. 2008. Available from: http://repositoriUSU. AC.id/handle/123456789/7949.

14. Costa SM, Vasconselos M, Abreu MHNG. High dental caries among adults aged 35 to 44 years: case-control study of distal and proximal factors. Int J. Environ Res Public Health. 2013;10(6):2401-2411.

15. Zemaitiene $\mathrm{M}$, Grigalauskiene R, Vasiliauskiene I, Saldunaite K, Razmiene J, Slabsinskiene E. Prevalence and severity of dental caries among 18-year-old Lithuanian adolescents. Medicina-Original Research Article. 2016;52(1):54-60.

16. Suratri MAL, Indirawati TN, Setiawaty V. Correlation between dental health maintenance behavior with dental carius status (DMF-T) [internet]. Bali Medical Journal. 2018;7(1):56-60 https://www. balimedicaljournal.org/index.php/bmj/issue/ view $/ 24$.

17. MA Budisuari, Oktarina, MA Mikrajab. Hubungan pola makan dan kebiasaan menyikat gigi dengan kesehatan gigi dan mulut (karies) di Indonesia. Buletin Penelitian Sistem Kesehatan. 2010;13(1):83-91.

18. Sharda AJ, Shetty S. Relationship of periodontal status and dental caries status with oral health knowledge, attitude, and behavior among professional students in India. Int J. Oral Sci. 2009;1(4):196-206.

19. Ejiofor ZI, Warthington HV, Walsh T, O'Malley L, Clarkson JE, Macey $\mathrm{R}$ et al. Water fluoridation for the prevention of dental caries. Cochrane Database of Systemic Reviews. 2015;6:1-3 DOI: 10.1002/14651858.CDO/0856. pub.2.

20. Moslemi M, Khalili Z, Karimi S. Fluorida concentration of bottled water and tap water in Tehran, Iran. J. Dent. Res Dent Prospect. 2011;5(4):132-135. 
21. Widana GAB, Astawa KP, Nida IKPS. Analisis Ion Fluorida (F-) dalam air minum kemasan, pam, mata air di wilayah Kecamatan Buleleng, Bali. Seminar Nasional Kimia \& Pendidikan Kimia VI, Surakarta, 21 Juni 2014: hal. 536-542. ISBN: 979363174-0

22. Ramezani G, Valaie N, Rakhsan V. The effect of water fluorida concentration on dental caries and fluorosis in five Iran provinces: A multi-center two-phase study. Dental Research Journal. 2015;12(1):31-37.

23. Slade GD, Sanders AL, Do L, Thomson R, Spencer AJ. Effects of fluoridated drinking water on dental caries in Australian adults. Journal of Dental Research. 2013;92(4):376382. 